\title{
MORPHOLOGICAL RESEARCH OF PLACENTA IN WOMEN WITH PRETERM LABOR
}

\begin{abstract}
Summary. Preterm labor is one of the most current problems of modern medicine. Preterm labor is defined as the birth of a child in the gestation period less than 37 full weeks of gestation and is the second most common cause (after congenital anomalies) of neonatal mortality [3]. The highest percentage of morbidity and mortality occurs in children born to gestational age less than 32 weeks, although the proportion of these newborns is $16 \%$ of all preterm infants [4]. Preterm labor is a polyetiology problem that depends on many factors. One of the major problems is the formation of placental dysfunction, which manifests itself by morphofunctional changes in the placenta associated with violation of uterine-placental circulation.

The aim of the study - to obtain the peculiarities of placentas' histological condition in women with burdent anamnesis and preterm labor with different Apgar point scale of newborn.

Materials and Methods. A total of 19 placentas of women with preterm labor were observed in Maternal Hospital No. 5 of Odesa, Ukraine. We studed their residence areas, obstetrical and gynacology anamnesis, current pregnancy and labor anamnesis. We examined the ultrasound datas of the newborns, studied their anthropometric, Apgar scale and histology of placentas' datas. All interviewed women were devided into two groups: less than 35 years old -12 women of the group 1 and more than 35 years old - 7 women, it was the group 2. The average age of the examined groups was 31.3 years old. Statistical datas processing was carried out by using the Fisher angular transformation. The degree of probability $(P)$ between two comparative values was considered to be statistically valid when $\mathrm{P}<0.05$

The research results showed that all elder women were married, lived in ecoregions of the city, had more often revolved to artificial reproductive technologies, had singleton gestation compared to younger group of patients. Newborns of women afer 35 had better points of Apgar scale and no one had IUGR compared to newborns of the younger women. Signs of placenta dysfynction were detected in placentas of both groups of women.

Conclusions. In our investigation the women of different age groups with preterm labor had signs of placenta dysfunction but women after 35 years had better datas of newborn babies according to Apgar scale and absence of IUGR. Probably, it is connected with residency, official marriage and better preconceptional preparation in this group.
\end{abstract}

Key words: preterm placenta; labor dysfunction; newborns.

INTRODUCTION Preterm labor is one of the most current problems of modern medicine. Preterm labor is defined as the birth of a child in the gestation period less than 37 full weeks of gestation and is the second most common cause (after congenital anomalies) of neonatal mortality [3]. The highest percentage of morbidity and mortality occurs in babies born to gestational age less than 32 weeks, although the proportion of these newborns is $16 \%$ of all preterm infants [4]. Preterm labor is a polyetiology problem that depends on many factors. One of the major problems is the formation of placental dysfunction, which manifests itself by morphofunctional changes in the placenta associated with violation of uterine-placental circulation. Placental dysfunction and fetoplacental malnutrition as the main one with its manifestations, which completely influences intrauterine development and fetal formation, is manifested by changes in all structural units and is the result of the immaturity of the villous tree. The result is a violation of the growth and development of the fetus in different trimesters of pregnancy and its premature termination [3]. An important role in the structural stability of the villous tree is played by the complex system of ties, which includes anchor villi, secondary fibrinoid compounds of the branches with basal plate, membranes and a choroid plate, as well as with each other and the villi of the neighboring cotylonone $[1,2]$.

The aim of the study - to obtain the peculiarities of placentas' histological condition in women with burdent anamnesis and preterm labor with different Apgar point scale of newborn.

MATERIALS AND METHODS Under observation in connection with preterm labor, there were 19 women in the Maternity Hospital No. 5 in Odesa in the period from September to December 2018. The features of their place of residence, obstetrical and gynecological and family history, features of the pregnancy and childbirth were studied. The results of ultrasound examinations of children were studied and the anthropometric data of newborns were obtained, their assessment on the Apgar scale was given and a histological analysis of the placentas of newborns was performed. Women in group I gave birth from 25 to 36 weeks of gestation, from 25 to 32 weeks accounted $49 \%$. In women of the group 2, childbirth was observed from 29 to 36 weeks, and in $57 \%$ of cases childbirth was in the period from 29 to 31 weeks of gestation.

RESULTS AND DISCUSSION An average from 8 to 10 years of females in groups 1 and 2 suffered from infertility, $42 \%$ were residents of the central regions of Odesa, $33 \%$ lived in residential areas of the city and $25 \%$ lived in the ecoregions of Odesa city, $67 \%$ of them were officially married. Among women of group 2, $14 \%$ lived in the central regions of the city, $28 \%$ - in the bedroom suburb and $58 \%$ were residents of Odesa regions, $100 \%$ of the interviewed of older age group were officially married. Pregnancy as a result of ART was reported in $25 \%$ of women in group 1,29\% of women in group 2 used ART, that is because of burdent obstetrical and gynacology anamnesis. In this case, in elderly women, in all cases, singleton gestation were obtained, and in women under the age of 35, in all cases, used ART multiple pregnancies were observed. Vaginal delivery occurred in $67 \%$ of young women and $71 \%$ of older women. The average duration of delivery of women in the group 1 amounted to 8 hours 03 minutes, and women in the group 2 - 6 hours 28 minutes, because of the parity, $58 \%$ of the group 1 and $57 \%$ of the group 2 gave birth as nulliparas. The pathological quantity of amniotic fluid (oligo- or poly) was noted in $75 \%$ of women in the group 1 and $71 \%$ of women in babies in women younger than the age group and in $14 \%$ of babies of women older than age. Female babies were 
more often born in women of the group $2-57 \%$, and in women of the group I of our study, male were born in $87 \%$ of cases. The average weight of infants at birth in younger women was $2107 \mathrm{~g}$, the average height of children was 45 $\mathrm{cm}$, and in women of the older age group the average weight of children was $2039 \mathrm{~g}$, the average height was also $45 \mathrm{~cm}$. The average score of the newborns of women in the group 1 on the Apgar scale on the first minute was 7 points, on the fifth -7 points. For women of the group 2, the average score on the first minute of life was 7 points, on the fifth minute -8 points that can indicate on better intrauterine and intrapartum conditions of these babies compared with newborns of the first women's group. Intrauterine growth restriction (IUGR) in women of the group 1 was observed in $33 \%$ of cases, in women of the group 2, was not found, placenta dysfunction, which was confirmed histologically suspected in $26 \%$ of women in the group 1 and $32 \%$ in women of the group 2, that means that placental compensation opportunities in these cases were better. The taking of material for morphological research was carried out in accordance with generally accepted recommendations [5]. The fragment of the placenta was fixed in $10 \%$ formalin solution. Paraffin sections on which the histological study was performed, painted using the following methods: a) coloration with hematoxylin-eosin - this technique gives a general idea of the structure of the body, well revealing all cellular elements and some non-cellular structures. On the glass, pour a filtered solution of Bemer's hematoxylin, leave for 5-10 minutes. Pour the hematoxylin back into the flask, immerse the cuts in water for 1-10 minutes. Illuminate $1 \%$ with hydrochloric acid and again immerse in clean tap water until the slicing is done (30 min.). Colors $1 \%$ of eosin for 1-2 min. And they are immersed in water, and then at $70^{\circ}$ and $96^{\circ}$ in the alcohols. Dip it with filter paper and immerse it in xylene to illuminate the sections, and then enclose the balm. The nuclei acquire a reddishpurple color with a distinct nucleolus and chromatin, and the cytoplasm is moderately pinkish-yellowish (E. Pearce, 1962); b) staining with Pikrofusin for Van Gison - this technique can detect fibrin among the masses of fibrinoid. On the glass, pour one part of the official solution of iron and two parts of the ferruginous hematoxylin for 5 minutes. Pour the paint, rinse with water and immerse it in water. Illuminate with $1 \%$ hydrochloric acid and immerse in water for a twist of sections - 15-30 minutes. Pyrofuksin color - 3-5 minutes. Immerse cuts in water for 1 to 10 minutes and brighten with $1 \%$ hydrochloric acid and then again immerse in clean tap water to make the slices smooth $-30 \mathrm{~min}$. then at $70^{\circ}$ and $96^{\circ}$ the alcohols. Dip it with filter paper and immerse it in xylene to illuminate the sections, and then enclose the balm.

\section{СПИСОК ЛІТЕРАТУРИ}

1. Основи патології захворювань по Робінсу та Котрану / В. Кумар, А. К. Аббас, Н. Фаусто, Д. К. Астер. - 2014. - Т. І, гл. 1-10. -549 с.

2. Воскресенский С. Л. Оценка состояния плода. Кардиотокография. Допплерометрия. Биофизический профиль: учеб. пособ. - Мн. : Книжный Дом, 2004. - 304 с.

3. Гулькевич Ю. В. Патология последа человека и ее влияние на плод / Ю. В. Гулькевич, М. Ю. Макавеева, Б. И. Никифоров. - Мн. : Беларусь, 1968. - 229 с.

4. Плацента людини / А. В. Колобов, В.А.Цинзерлинг, Є. А. Смірнова [та ін.] // Морфофрункціональні основи. -2011. -78 с.
In the group 1, the oval form of the placenta prevailed, while in the group 2 it was a round form. The central attachment of the umbilical cord in the group 1 occurs in every third woman, and in the group 2 in each second woman. The first attachment of the umbilical cord to the group 1 was found in 3 cases, and in the group 2 - in one case. Paracentral fixation occurred in group 1 in each second woman, in the group 2 also in each second woman. In each group there was a swelling of the umbilical cord. In the group 2, in one case, the fertile membranes were stained green. All children were born alive. In a microscopic study, hemodynamic disorders (blood in the intervertebral space, hypo- and abacular villi) were determined in the constellations, and in group 1 in both cases and in group 2, in one case, there were infarctions in the form of villous necrosis with clearly delimited dense areas surrounded by blood in between the pharynx space. In two cases in the group 1 and in one case in the group 2, there was retroplacental hematoma with characteristic changes in the basal plate in the form of swelling with plasmorrhagia and the presence of trommel. In 4 cases, in the group 1 and in 2 cases in the group 2, the involutivedystrophic processes were determined in the form of functionalinactive syncytial nodes, which merged into homogeneous masses of nuclei, had no clear boundaries, were petrified, and painted for Van Gizon collagen fibers acquired a yellow color and folding in places of fibrinoid changes. Stroma villi lost its structure, homogeneous masses were determined in separate sites with the phenomena of karyorhexis. In the intervertebral space there were areas with a small number of red blood cells, and in places completely filled with blood. Hyperplasia of the villi was accompanied by hyperplasia of the vessels in them (5-8 vessels), most of which formed syncytocapillary membranes. In the study of the umbilical cord, edema was observed, with the formation of large cavities, in the lumen of the vein there was a peptide epithelium, thickening of the venous wall. In the study of the membranes, the thickening of the compact layer was determined.

CONCLUSIONS The results of the study confirmed that women over 35 years of age are more likely to have induced pregnancies than younger women. Signs of placental dysfunction were identified in both groups. Women of the group 2 had better datas of Apgar scale of their newborns and absence of intrauterine growth restriction. That may be explained with better placental compensatory function, better residency, official marriage and better preconceptional preparation in this women.

Prospects for further research In further research, we aim to continue our study of the preterm labor, reccurent pregnancy losses problems with in-depth study of its genetically acquired and immune factors acquired throughout life.

5. Милованов А. П. Патология системы мать-плацента-плод : руководство для врачей / А. П. Милованов. - М. : Медицина, 1999. - 448 с.

6. Школьна І. І. Особливості структури волосся жінок, які народили передчасно, та їх новонароджених дітей / І. І. Школьна, В. Е. Маркевич // Морсоологія - 2017. - Т. 11, № 1. - С. 62-67.

7. DeCherney A. H. Current Obstetric \& Gynecologic Diagnosis \& Treatment. $9^{\text {th }}$ Edition / A. H. DeCherney, L. Nathan. -2008. - P. 187-222.

8. Placental growth factor as a marker of fetal growth restriction caused by placental dysfunction / S. J. Benton, L. M. McCowan, A. E. P. Heazell [et al.] // Placenta. - 2016. - Vol. 42. - P. 1-8. 
9. Low maternal placental growth factor is associated with abnormal placental morphology in fetuses with suspected intrauterine growth restriction / S. Benton, J. Yockell-Lelièvre, D. Grynspan [et al.] // Placenta. - 2014. - Vol. 35(9). - P. A44.

10. Blaas H.-G. K. Detection of structural abnormalities in the first trimester using ultrasound / H.-G. K. Blaas // Best Practice \& Research Clinical Obstetrics \& Gynaecology. - 2014. - Vol. 28 (3). - P. 341-353.

11. Markers of early endothelial dysfunction in intrauterine growth restriction-derived human umbilical vein endothelial cells revealed by 2D-DIGE and mass spectrometry analyses / A. Caniuguir, B. J. Krause, C. Hernandez [et al.] // Placenta. - 2016. - Vol. 41. P. 14-26.

12. Proteome differences in placenta and endometrium between normal and intrauterine growth restricted pig fetusesm / F. Chen, T. Wang, C. Feng [et al.] // PLoS ONE. - 2015. - Vol. 10 (11). P. e0142396.

13. Galan H. L. Protocol 40: Fetal Growth Restriction. In Protocols for High-Risk Pregnancies: An Evidence-Based Approach. $6^{\text {th }}$ Edition / H. L. Galan ; In J. T. Queenan, C. Y. Spong, C. J. Lockwood eds. - John Wiley \& Sons, Ltd. - 2015. - Ch. 40.

14. The long non-coding RNA NEAT1 is increased in IUGR placentas, leading to potential new hypotheses of IUGR origin/ development / S. Gremlich, F. Damnon, D. Reymondin [et al.] // Placenta. - 2014. - Vol. 35 (1). - P. 44-49.

15. Grigsby P. L. Animal models to study placental development and function throughout normal and dysfunctional human pregnancy / P. L. Grigsby // Seminars in Reproductive Medicine. - 2016. Vol. 34 (01). - P. 011-016.

16. Vitamin $D$ rescues dysfunction of fetal endothelial colony forming cells from individuals with gestational diabetes / J. Gui, A. Rohrbach, K. Borns [et al.] // Placenta. - 2015. - Vol. 36 (4). P. $410-418$
17. Khalil A. How to record uterine artery Doppler in the first trimester / A. Khalil, K. H. Nicolaides // Ultrasound in Obstetrics and Gynecology. - 2013. - Vol. 42 (4). - P. 478-479.

18. Endothelial eNOS/arginase imbalance contributes to vascular dysfunction in IUGR umbilical and placental vessels / B. J. Krause, I. Carrasco-Wong, A. Caniuguir [et al.] // Placenta. - 2013. - Vol. 34 (1). - P. 20-28

19. Martín-Estal I. Intrauterine growth retardation (IUGR) as a novel condition of insulin-like growth factor-1 (IGF-1) deficiency / I. MartínEstal, R. G. De La Garza, I. Castilla-Cortázar // Reviews of Physiology, Biochemistry and Pharmacology. - 2016. - Vol. 170. - P. 1-35.

20. First-trimester contingent screening for trisomy 21 by biomarkers and maternal blood cell-free DNA testing / K. H. Nicolaides, D. Wright, L. C. Poon [et al.] // Ultrasound in Obstetrics and Gynecology. - 2013. - Vol. 42 (1). - P. 41-50.

21. Angiogenesis in the Placenta: The Role of Reactive Oxygen Species Signaling / R. D. Pereira, N. E. De Long, R. C. Wang [et al.] // BioMed Research International. - 2015. - Article ID 814543. - P. 12.

22. Normal and Abnormal US Findings in Early First-Trimester Pregnancy: Review of the Society of Radiologists in Ultrasound 2012 Consensus Panel Recommendations / S. K. Rodgers, C. Chang, J. T. DeBardeleben, M. M. Horrow // RadioGraphics. - 2015. Vol. 35 (7). - P. 2135-2148.

23. Sathyanarayana S. First trimester phthalate exposure and male newborn genital anomalies / S. Sathyanarayana, R. Grady, E. S. Barrett // Environmental Research. -2016. - Vol. 151. -P. 777-782.

24. Oxidative stress as common trait of endothelial dysfunction in chorionic arteries from fetuses with IUGR and LGA / D. Schneider, C. Hernández, M. Farías [et al.] // Placenta. - 2015. - Vol. 36 (5). P. 552-558.

25. Winterhager E. Transplacental nutrient transport mechanisms of intrauterine growth restriction in rodent models and humans / E. Winterhager, A. Gellhaus // Frontiers in Physiology. - 2017. - No. 27.

\section{МОРФОЛОГІЧНЕ ДОСЛІДЖЕННЯ ПОСЛІДУ В ЖІНОК ІЗ ПЕРЕДЧАСНИМИ ПОЛОГАМИ}

Резюме. Невиношування вагітності належить до числа найактуальніших проблем у сучасний медицині. Цим терміном визначають народження дитини в терміні гестації менше ніж 37 повних тижнів, що є другою за розповсюдженням причиною (після уроджених аномалій) неонатальної смертності. Найвищий відсоток захворюваності й смертності припадає на дітей, які народилися у терміні гестації менше 32 тижнів, хоча частка цих новонародженних складає 16 \% від усіх недоношених новонароджених. Передчасні пологи - поліетіологічна проблема, що залежить від багатьох фракторів. Однією з провідних проблем $€$ формування плацентарної диссункції, яка проявляється морфоорункціональними змінами в плаценті, що пов'язані 3 порушенням матково-планцентарного кровообігу.

Мета дослідження - вивчити особливості гістологічного стану плаценти у жінок з обтяженим акушерсько-гінекологічним анамнезом та пологами до терміну, діти яких при народженні мали різну оцінку за шкалою Апгар.

Матеріали і методи. У зв'язку зі збільшенням передчасних пологів у КЗ “Пологовий будинок № 5" під спостереженням перебувало 19 жінок з вересня до грудня 2018 р. Вивчено особливості їх місць проживання, акушерсько-гінекологічного та сімейного анамнезів, перебігу даної вагітності та пологів. Проаналізовано результати ультразвукових обстежень дітей та отримано антропометричні дані новонароджених, надано оцінку за шкалою Апгар та проведено гістологічний аналіз послідів народжених дітей. Для клінічної оцінки виявлення особливостей перебігу вагітностей, пологів та послідів у жінок різних вікових груп поділили на дві групи: до 35 років - 12 жінок (перша група) та після 35 років - 7 жінок (друга група). Середній вік обстежених жінок становив 31,3 року. Статистичну обробку даних проведено з використанням кутового критерію перетворення Фішера. Показник ступеня вірогідності (р) між двома порівнювальними величинами вважали достовірним при значеннях р<0,05.

Результати досліджень та їх обговорення. Старші за віком жінки, які проживали в екологічно сприятливих районах Одеської області й перебували в шлюбі та яким застосовували допоміжні репродуктивні технології (ДРТ), мали одноплідну вагітність, порівняно з жінками першої групи, котрі жили в центральній частині міста з гіршими екохарактеристиками, перебували в незаконному шлюбі й при цьому частіше мали багатоплідну вагітність за допомогою ДРТ, у них були гірші перинатальні показники. Вагітності, індуковані за допомогою ДРТ, спостерігали частіше у жінок другої групи. При цьому новонароджені діти від жінок із другої групи мали кращі показники за шкалою Апгар і не мали синдрому внутрішньоутробної затримки, порівняно з новонародженими у жінок першої групи. Ознаки диссункції плаценти при цьому спостерігали як у жінок першої, так і другої груп. 
Висновки. Кращі показники життєдіяльності за шкалою Апгар і відсутність ознак внутрішньоутробної затримки розвитку плода були виявлені у дітей від жінок старшої вікової групи. Це може бути пов'язано з кращими умовами проживання, більш стабільним соціальним статусом і кращою преконцептуальною підговтовкою даної вікової групи.

Ключові слова: дисфункція плаценти; передчасні пологи; новонароджені.

(СВ. А. Ситникова, О. Н. Надворная, А. В. Кашиян

Одесский национальный медицинский университет

МОРФОЛОГИЧЕСКОЕ ИССЛЕДОВАНИЕ ПОСЛЕДА У ЖЕНЩИН С ПРЕЖДЕВРЕМЕННЫМИ РОДАМИ

Резюме. Невынашивание беременности относится к числу наиболее актуальных проблем современной медицины. Этим термином определяется как рождение ребенка в сроке гестации менее чем 37 полных недель, что является второй по распространенности причиной (после врожденных аномалий) неонатальной смертности. Самый высокий процент заболеваемости и смертности приходится на детей, родившихся в сроке гестации менее 32 недель, хотя доля этих новорожденных составляет 16 \% всех недоношенных новорожденных. Преждевременные роды - полиэтиологическая проблема, что зависит от многих факторов. Одной из ведущих проблем является формирование плацентарной диссункции, которая проявляется морфоофункциональными изменениями в плаценте, связанными с нарушением маточно-планцентарного кровообращения. Цель исследования - изучить особенности гистологического состояния плаценты у женщин с отягощенным акушерско-гинекологическим анамнезом и родами до срока, дети которых при рождении имели разную оценку по шкале Апгар.

Материалы и методы. Под наблюдением находилось 19 женщин, у которых произошли преждевременные роды в КУ “Родильный дом № 5" с сентября по декабрь 2018 г. Изучали особенности их места жительства, акшерско-гинекологический и семейный анамнезы течения данной беременности и родов. Проанализированы результаты ультразвуковых обследований детей, а также получены антропометрические данные новорожденных, дано оценку их по шкале Апгар, проведен гистологический анализ последов. Для кличнической оценки полученных результатов все женщины в данном исследовании были разделены на две группы: до 35 лет - 12 женщин, это первая группа и после 35 лет - 7 женщин (вторая группа). Средний возраст обследуемых женщин составил 31,3 года. Статистическую обработку данных проведено с использованием углового критерия Фишера. Показатель степени достоверности (р) между двумя сравниваемыми величинами считался достоверным при значениях $p<0,05$.

Результаты исследований и их обсуждение. Старшие по возрасту женщины, проживавшие в экологически благоприятных районах Одесской области, находившиеся в законном браке и прибегавшие к вспомагательным репродуктивным технологиям (ВРТ), беременели одноплодной беременностью, по сравнению с женщинами первой группы, котрые жили в центральной части города с худшими экохарактеристиками, находились в незаконном браке и при этом чаще имели многоплодные беременности при помощи ВРТ, у них были худшие перинатальные показатели. Беременности, индуцированные с помощью ВРТ, наблюдались чаще у женщин второй группы. При этом новорожденные дети от женщин второй группы имели лучшие показатели по шкале Апгар и не имели синдрома внутриутробной задержки развиия по сравнению с новорожденными у женщин первой группы. Признаки диссункции плаценты при этом наблюдались как у женщин первой, так и второй групп.

Выводы. Лучшие показатели жизнедеятельности по шкале Апгар и отсутствие признаков внутриутробной задержки развития плода были обнаружены у детей от женщин старшей возрастной группы. Это может быть связано с лучшими условиями проживания, более стабильным социальным статусом и лучшей преконцептуальной подговтовкой данной возрастной группы.

ключевые слова: дисфункция плаценты; передчасные роды, новорождённые.

Address for correspondence: O. M. Nadvorna, Odesa National Medical University, Valikhovskyi alley, 2, Odesa, 65000, Ukraine, e-mail: olga.nadvorna@gmail.com 